\title{
Revision of Myxobolus heterosporus Baker, 1963 (syn. Myxosoma heterospora) (Myxozoa: Myxosporea) in African records
}

\author{
A. El-Mansy* \\ National Institute of Oceanography and Fisheries, 101 Kaser El-Einii St., Cairo, Egypt
}

\begin{abstract}
There is uncertainty regarding the validity of Myxobolus heterosporus Baker, 1963. The present study revises the taxonomy, using specimens isolated from plasmodia situated in the infected cornea of Oreochromis aureus, O. niloticus or Tilapia zillii inhabiting the River Nile, Egypt. In addition, histological effects of the parasite on the infected tissue were examined. The spores of M. heterosporus had a variety of shapes expressing remarkable heteromorphism. Five main Мухоbolus-like spore types and tailed-spores were found. All forms were photographed, measured, sketched and described. Light and electron microscopy supported that spores of a Myxobolus-like morphology co-existed with so-called tailed-spores in one plasmodium. Some transitional stages from Myxobolus-like spore types to tailed-spores were observed. Therefore, some tailed-spores may be simply heteromorphs of Myxobolus.
\end{abstract}

KEY WORDS: Myxosporea · Revision · Myxobolus heterosporus · Heteromorphism · Plasmodium • Cornea $\cdot$ Oreochromis aureus $\cdot$ O. niloticus $\cdot$ Tilapia zillii $\cdot$ River Nile

\section{INTRODUCTION}

In Africa, the first description of myxosporeans Bütschli, 1881 was given by Baker (1963). This was followed by a number of studies, such as those of Paperna (1968), Abolarin (1974), Obiekezie \& Okaeme (1990) and Fomena \& Bouix (1994), Kostoingue \& Toguebaye (1994), Fomena \& Bouix (1997). Studies in Egypt include Fahmy et al. (1971), Imam et al. (1987), Ashmawy et al. (1989), Abdel-Ghaffar et al. (1995), Koura (2000), Ali et al. (2002) and El-Mansy (2002).

The present study provides a revision of Myxobolus heterosporus, a species which was established by Baker (1963), who described the spores of $M$. heterosporus from trophozoites and spores adjacent to blood capillaries, and sinusoids of liver and spleen. In addition, spores were found in the kidney of Oreochromis esculentus Graham, O. variabilis Boulenger, O. niloticus L. and in the spleen of Haplochromis sp. These fishes were caught in Lakes Victoria and George in East Africa. Three different spore types were distinguished in $M$. heterosporus according to their respective simi- larities in shape and size. In fact, there were considerable differences between all the 3 types of $M$. heterosporus. They were described by Baker (1963) as follows: Type 1: spores ovoid, ellipsoidal or rarely round, measuring $12.5(8.5-17) \times 8.3(6.5-11) \mu \mathrm{m}$, with a blunt anterior end. The polar capsules were short ovoid, not more than one-third the length of the spore, and measured $4.1(2.0-5.5) \times 2.3(1.5-3.5) \mu \mathrm{m}$, and a small intercapsular appendage was visible. Type 2: spores ovoid or pyriform, measuring $11.6(9.0-15.0) \times 8.0(6.5-10.5)$ $\mu \mathrm{m}$, with a pointed end. The 2 pyriform polar capsules, about half the spore length, measured $4.7(3.0-7.0) \times$ 2.1 (1.5-3.0) $\mu \mathrm{m}$. Type 3: spores ovoid or ellipsoidal, measuring $12.5(10.0-14.5) \times 7.2(6.3-8.0) \mu \mathrm{m}$, with a pointed anterior end. Two pyriform or ovoid polar capsules, sometimes curved and more than half the spore length, measured $7.5(5.5-9.5) \times 2.3(1.8-3.0) \mu \mathrm{m}$.

Myxobolus heterosporus (syn. Myxosoma heterospora) as described by Baker (1963) should be reconsidered for the following reasons:

(1) Among fish examined by Baker were 2 juveniles from unnamed species. 
(2) Baker described Myxobolus heterosporus from what he called trophozoites and spores adjacent to blood capillaries and sinusoids of liver, spleen and from the kidney. In addition, Baker (1963) and Landsberg (1985) reported an absence of cysts in spleen and kidney where melano-macrophage centers were accumulation sites for spores. The variation between the 3 spore types of $M$. heterosporus and the inadequate description of the trophozoites led Landsberg (1985) to assume that Baker probably confused melano-macrophage centers and trophozoites. In addition, Landsberg (1985) reported that the spore formation occurs elsewhere and that spleen and kidney might act as concentrating areas for scattered spores, thus possibly providing useful knowledge of myxosporean infections. Dyková (1982) suggested that melano-macrophages are able to transport mature spores to the melano-macrophage centers where they are destroyed. Therefore, the myxosporean parasite should be described from its original plasmodium (Lom \& Arthur 1989, Molnár 1994). This was discussed by Landsberg (1985), Hegazy (1999) and El-Mansy \& Abdel-Ghaffar (2003), who reported that various spores may come from their original plasmodia to the kidney via blood. In this case, the kidney infection may be used as diagnostic evidence for the presence of myxosporeans but could not be used as taxonomic evidence, and further studies to detect their exact original sites is necessary.

(3) Unclear drawings and the lack of some important characters such as the number of polar filament coils led to an incomplete description. Therefore, the species described by Baker should be considered as of uncertain taxonomic status. Lom (1969) considered the number of polar filament coils an important taxonomic character.

(4) In addition, all descriptions and dimensions of spores were based on fixed material which led to atypical forms of spores.

Therefore, the main aim of the present study was to describe Myxobolus heterosporus from its original plasmodium in the infected cornea of the eye of some tilapias in the River Nile. The description includes histology, morphology, drawings and dimensions. In addition, examination by light and electron microscopy provided some evidence of presence and transitional stages from Myxobolus-like spores to what are called tailed-spores.

\section{MATERIALS AND METHODS}

A total of 375 tilapian fishes, 167 Oreochromis (syn. Tilapia) aureus Steindachner, 1864; 153 O. niloticus Linnaeus, 1757 and 55 T. zillii Geravais, 1848, were collected from the River Nile at the Pharaonic Village in Giza City from October 2001 to July 2002. A few examinations were also carried out in 2003. Immediately after collection the fish were transported live to the laboratory where their length and weight were measured. They were dissected and the eyes examined for myxosporean parasites under stereo and light microscopes. The individuals were more than $1 \mathrm{yr}$ old and measured 12 to $21 \mathrm{~cm}$ in length and weighed 46 to $114 \mathrm{~g}$. The prevalence of infection was calculated. Plasmodia were carefully separated from the infected cornea. Fresh smears from each plasmodium were examined frequently. Each spore form was photographed, drawn and measured. Measurements were made according to the method recommended by Lom \& Arthur (1989). Spores were placed in glycerolgelatine to make permanent preparations. For histological examinations, infected eyes were fixed in Bouin's solution, embedded in paraffin wax, cut in 4 to $5 \mu \mathrm{m}$ thick sections and then were stained with hematoxylin and eosin (H\&E). For electron microscopy, plasmodia were fixed in $3 \%$ glutaraldehyde in $0.1 \mathrm{M}$ sodium cacodylate ( $\mathrm{pH} 7.4$ ) for at least $24 \mathrm{~h}$ and postfixed in $2 \% \mathrm{OsO}_{4}$ in the same buffer. Then the specimens were dehydrated in a series of graded ethanol, transferred to propylene oxide and embedded in araldite. Sections were cut with a glass knife on an LKB ultramicrotome and stained by using a Reichert ultrastainer with uranyle acetate and lead citrate before examination in a JEOL transmission electron microscope (TEM). For scanning, electron microscopy specimens were collected and fixed as above, then washed, dehydrated, sputtered with gold and finally examined by JEOL scanning electron microscope (SEM).

\section{RESULTS}

The total prevalence of infection with Myxobolus heterosporus was $44.5 \%$ (167 out of 375). In Oreochromis aureus the prevalence was 88\% (144 out of 167), in O. niloticus $9.8 \%$ (15 out of 153) and in Tilapia zillii $9.1 \%$ (5 out of 55). Cysts were detected from the beginning of November up to July. In $O$. aureus and $O$. niloticus the infection peaked during January and continued to June, thereafter decreased gradually in July. The spores disappeared by the end of July. No infection was recorded from October to February in T. zillii.

Plasmodia. A large number of white plasmodia measuring 0.5 to $2 \mathrm{~mm}(\mathrm{n}=25)$ were observed macroscopically (Fig. 1). Scanning electron microscopy indicated that the plasmodium cyst established within the inner wall of the cornea tissue and was surrounded by a smooth thin membrane (Fig. 2).

Histology. The growth of the plasmodium led to compression and fusion of the epithelial lining of the cornea tissue and occupied a wide area of the cornea 
Figs. 1 to 4. Fig. 1. Natural specimen of eye of Oreochromis niloticus showing white plasmodia (arrows) of Myxobolus heterosporus infected cornea. Fig. 2. Scanning electron micrograph shows plasmodium (P) of M. heterosporus embedded within the inner wall of cornea tissue (C) of $O$. aureus. Note a smooth thin membrane surrounds plasmodium cyst. Fig. 3. Photomicrograph of a Giemsa stained longitudinal section of eye of tilapia showing the growth of plasmodium (P) leading to pressure (arrowheads) and fusion of the epithelia lining cornea tissue (C). $(\times 75)$. Fig. 4. High magnification from a cross section of eye shows plasmodium. Near the plasmodium wall (a) early developmental stages (b), and at the center of plasmodium mature spores (c) can be clearly seen. Hema-toxylin and eosin $(\times 300)$
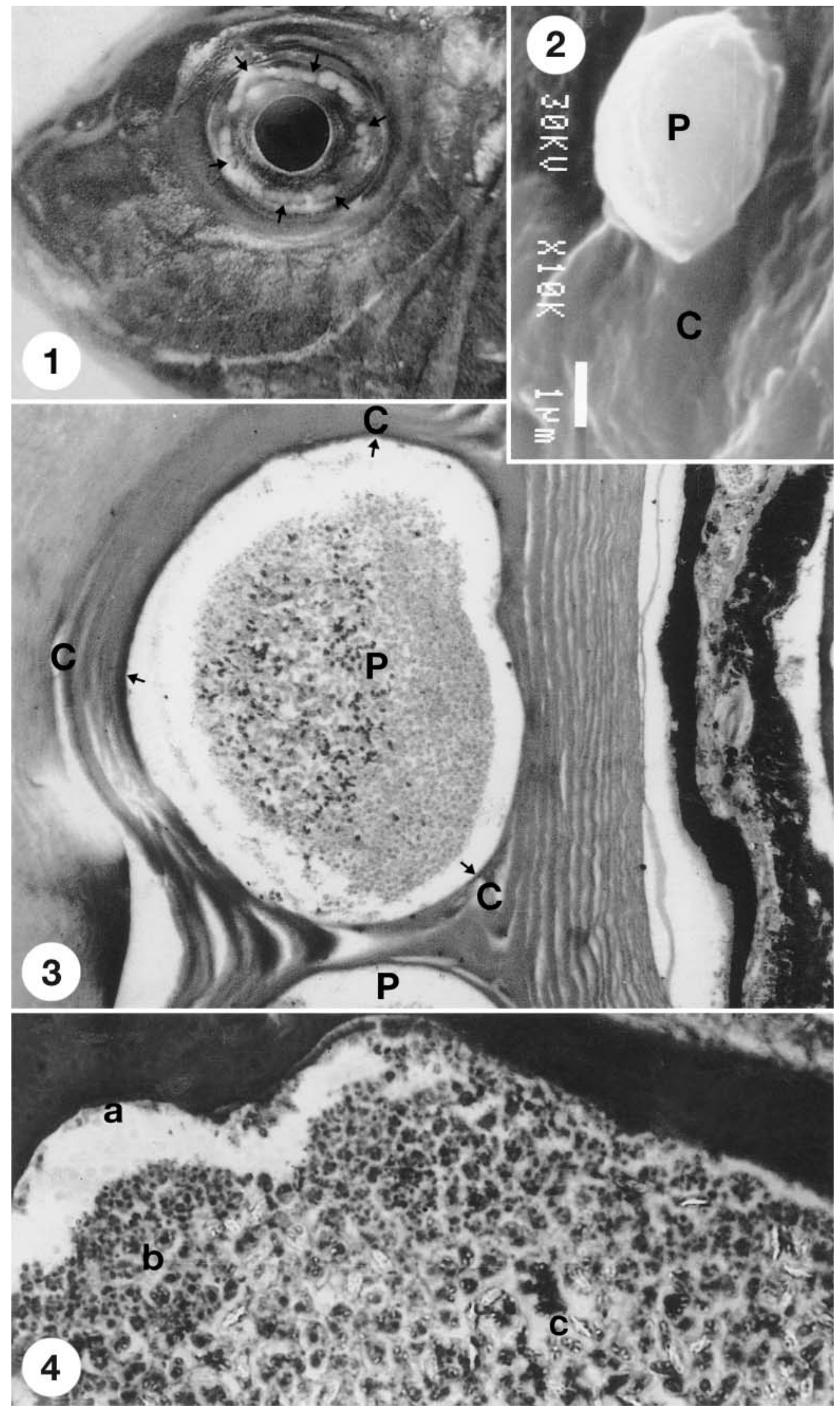
Table 1. Myxobolus heterosporus measurements $(\mu \mathrm{m})$ of types, stages, tailed-spores and abnormal forms, based on 48 spores

\begin{tabular}{|c|c|c|c|c|}
\hline \multirow[t]{2}{*}{ Spore } & Spore body & Polar capsules & \multirow[t]{2}{*}{ Tail } & \multirow[t]{2}{*}{ Total length } \\
\hline & Length Width & Length Width & & \\
\hline Type 1 & $14.9(14.2-15.6) \times 9.6(9.3-9.9)$ & $4.0(3.7-4.3) \times 2.6(2.4-2.8)$ & - & 14.9 \\
\hline Type 2 & $12.0(11.5-12.4) \times 10.6(9.9-11.2)$ & $4.4(3.7-5.0) \times 2.8(2.5-3.1)$ & - & 12.1 \\
\hline Type 3 & $8.1(7.4-8.7) \times 14.6(13.6-15.5)$ & $4.0(3.7-4.3) \times 2.7(2.2-3.1)$ & - & 8.1 \\
\hline Type 4 & $13.0(12.0-13.8) \times 5.9(4.9-7.4)$ & $4.5(3.7-5.0) \times 2.5(1.9-3.4)$ & - & 15.7 \\
\hline Type 5 & $13.0(12-6-13.4) \times 9.2(8.7-9.9)$ & $3.7(3.1-4.3) \times 2.8(2.5-3.1)$ & - & 13.0 \\
\hline Stage 1 & $12.4(12.3-12.6) \times 12.0(11.4-12.4)$ & $4.1(3.1-5.0) \times 2.9(2.5-3.1)$ & - & 12.4 \\
\hline Stage 2 & $16.3(15.7-16.8) \times 13.8(13.4-14.4)$ & $4.5(4.2-4.8) \times 2.7(2.4-3.0)$ & - & 16.3 \\
\hline Stage 3 & $18.9(18.0-19.8) \times 15.2(15.0-15.5)$ & $4.3(3.7-5.0) \times 2.4(1.5-3.1)$ & - & 18.6 \\
\hline $\left.\begin{array}{l}\text { Stage } 4 \\
\text { (Tailed spore 1) }\end{array}\right\}$ & $16.4(15.5-17.3) \times 12.9(12.7-13.0)$ & $4.0(3.7-4.3) \times 2.7(2.5-3.1)$ & $5.1(4.8-5.6)$ & 22.8 \\
\hline Tailed spore 2 & $14.5(14.2-14.9) \times 9.6(9.3-9.9)$ & $4.3(3.7-5.0) \times 2.7(2.5-3.1)$ & $2.6(2.4-2.8)$ & 16.8 \\
\hline Tailed spore 3 & $17.3(16.6-18.0) \times 9.6(9.3-9.6)$ & $4.7(4.3-5.0) \times 2.8(2.5-3.1)$ & $4.5(3.6-5.3)$ & 21.8 \\
\hline Tailed spore 4 & $13.3(11.4-15.0) \times 9.2(8.7-9.9)$ & $4.7(4.3-5.0) \times 3.2(3.1-3.4)$ & $6.0(4.2-7.8)$ & 19.3 \\
\hline Tailed spore 5 & $16.1(14.8-17.4) \times 11.5(13.7-12.4)$ & $4.4(3.7-5.0) \times 4.2(2.8-5.5)$ & $8.7(6.6-10.8)$ & 24.8 \\
\hline Tailed spore 6 & $13.7(12.4-15.0) \times 10.8(10.5-11.2)$ & $4.7(3.7-5.6) \times 3.3(3.1-3.7)$ & $14.6(13.6-15.5)$ & 30.5 \\
\hline Tailed spore 7 & $15.5(14.2-16.7) \times 11.8(11.2-12.4)$ & $6.5(5.6-7.4) \times 3.1(2.5-3.7)$ & $32.0(27.9-36.0)$ & 47.5 \\
\hline (Abnormal 1) & $12.2(12.0-12.4) \times 6.4(6.0-6.5)$ & $2.5(1.9-3.1) \times 2.0(1.5-2.5)$ & - & 12.2 \\
\hline $\begin{array}{l}\text { Tailed spore } 8 \\
\text { (Abnormal 2) }\end{array}$ & $11.2(9.3-13.0) \times 9.0(8.6-9.3)$ & $4.1(3.1-5.0) \times 2.8(2.5-3.1)$ & $18.9(18.6-19.2)$ & 30.1 \\
\hline $\begin{array}{l}\text { Tailed spore } 9 \\
\text { (Abnormal 3) } \\
\text { Tailed spore } 10\end{array}$ & $14.3(13.0-15.6) \times 8.6(8.3-8.8)$ & $4.4(3.7-5.0) \times 2.4(2.2-2.5)$ & $13.2(13.1-13.2)$ & 27.5 \\
\hline (Abnormal 4) & $12.1(11.3-12.8) \times 7.5(6.6-8.3)$ & $3.8(3.0-4.5) \times 2.8(2.5-3.0)$ & $19.5(18.6-20.4)$ & 31.6 \\
\hline (Abnormal 5) & $15.5(14.2-16.8) \times 10.1(9.3-11.2)$ & $4.7(3.7-5.6) \times 2.8(2.5-3.1)$ & - & 15.5 \\
\hline (Abnormal 6) & $12.9(11.4-14.3) \times 13.2(12.8-13.5)$ & $4.9(3.8-6.0) \times 3.4(3.0-3.8)$ & - & 12.9 \\
\hline (Abnormal 7) & $16.2(15.5-16.8) \times 11.2(11.0-11.4)$ & $3.7(3.0-4.3) \times 2.6(2.2-3.0)$ & - & 16.2 \\
\hline Total dimensions & $14.1(13.2-15.0) \times 10.5(10.0-11.1)$ & $4.3(3.6-4.9) \times 2.8(2.4-3.2)$ & $12.5(11.3-13.7)$ & $\begin{array}{l}20 \mu \mathrm{m} \text { for all } 27.3 \mu \mathrm{m} \\
\text { for tailed ones }\end{array}$ \\
\hline
\end{tabular}

tissue (Fig. 3). Early developmental stages of the parasite were observed near the wall of the plasmodia and mature spores were located at the center (Fig. 4).

Spores. Five different forms of spores with a Myxobolus-like morphology, tailed-spores and some abnormal forms were observed in plasmodia of $M$. heterosporus.

Deposited material. Reference specimens of the present parasite were deposited in the protozoan col- lection of Natural History of the British Museum (accession numbers: 2002: 6: 11: 1, 2002: 6: 11: 2).

Etymology. Due to the very varied shapes of the spores of the present species isolated from their original plasmodia from the inner wall of cornea of Oreochromis aureus, O. niloticus and Tilapia zillii inhabiting the River Nile, it was named Myxobolus heterosporus.

Figs. 5 to 23. Myxobolus heterosporus. Light photomicrographs of fresh unfixed spores of various types (Figs. 5 to 8 (arrowhead)), immature stages (Figs. 8 (arrow) to 10), stage 4 so called tailed-spore 1 (Fig. 11), tailed-spores 2 to 7 (Figs. 12 to 17 ) respectively and abnormal forms 1 to 7 (Figs. 18 to 23) isolated from the plasmodium embedded within the inner wall of several tilapias caught from the River Nile. Note spores show wide variations in shape and size. (Scale bar $=6 \mu \mathrm{m}$ ). Fig. 5 . Spore type 1 (arrow). Note a little thickening at the posterior end of the spore. Spore type 2 (arrowhead) of sub-spherical shape. Fig. 6. Spore type 3 (arrow) where the width greatly exceeds the length. Fig. 7. Spore type 4 (arrow). Note a cup base-like appearance at the posterior end of the spore. Fig. 8. Spore type 5 (arrowhead) of ellipsoidal shape with round anterior and posterior ends. Figs. 8 to 10 . Spores of immature stages 1 to 3 (arrows) in different positions. Note the body of the spores is somewhat elongated to a change in shape from sub-spherical to ellipsoid. Fig. 11. Tailed-spore 1 (stage 4) (arrow) exhibits a short single curved tail at its posterior end. Fig. 12. Tailed-spore 2 (arrow) of a short tail. Fig. 13. Tailed-spore 3 (arrow) of a more elongated tail. Note that a triangular thickening at the base of sporoplasm is well discernible. Fig. 14. Tailed-spore 4 with a well-developed tail. Fig. 15. Tailed-spore 5 (arrow) with a more elongated tail. Fig. 16. Tailed-spore 6 (arrow) in oblique view. Note shell opening of spore and elongated tail. Fig. 17. Tailed-spore 7 (arrow) of a characteristic spore shape with longer tail. Fig. 18. Spores of abnormal form 1 in oblique view (arrowhead). Note unusual spore shape. Spore of abnormal form 2 (tailed-spore 8 ) (arrow) characterized by different aspects of tail which is degenerated or incompletely developed. Figs. 19 \& 20. Spores of abnormal form 3 (arrow) and abnormal form 4 (arrow) (tailed-spores $9 \& 10$ ) respectively of unusual shape with 4 polar capsules. Figs. 21-23. Spores of abnormal forms 5, 6 \& 7 (arrows) respectively with no tail. Note 3 polar capsules of different aspects showing either abnormal spore valve (Fig. 21) or unusual position of the polar capsule (Fig. 22). 

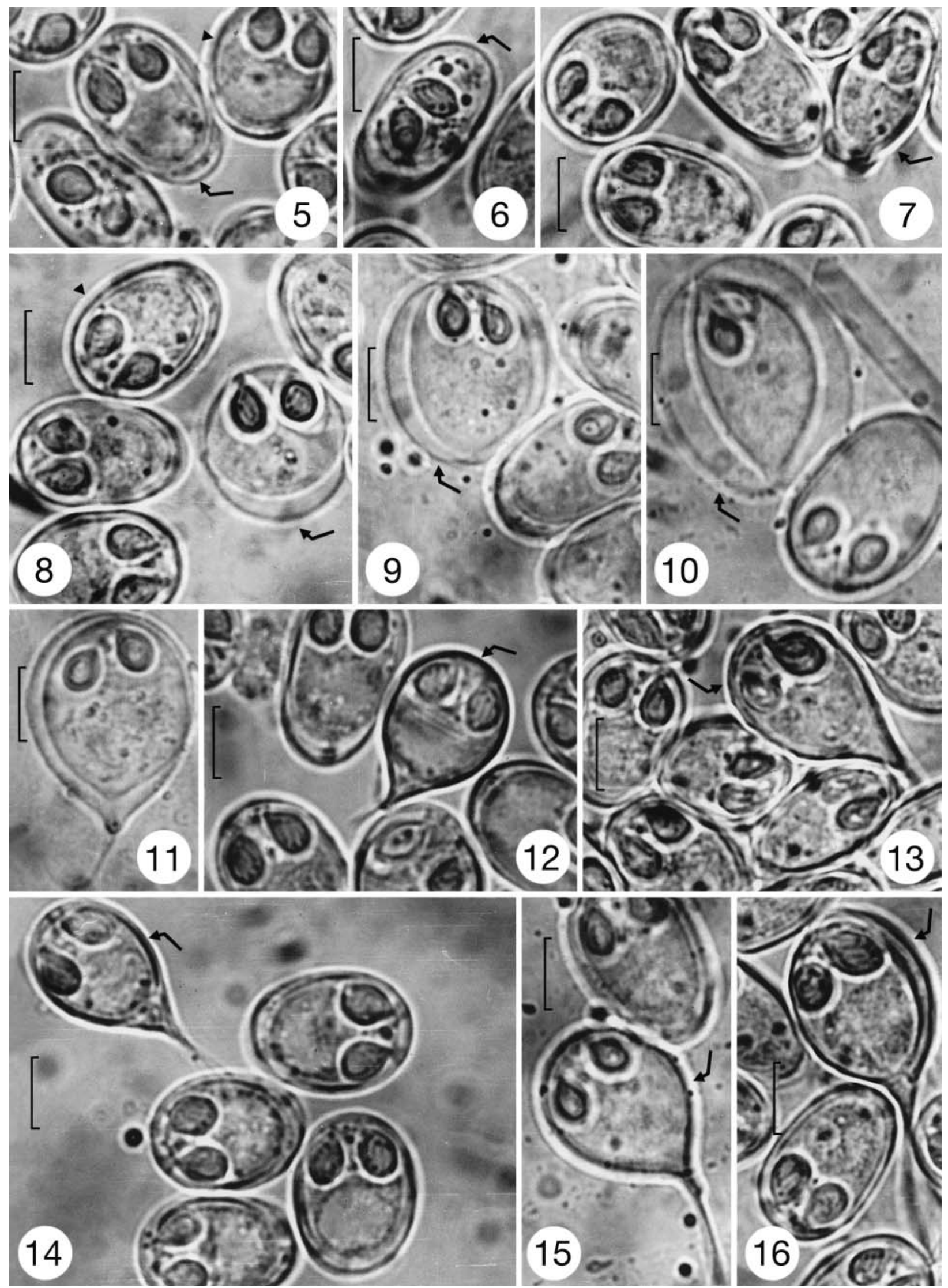

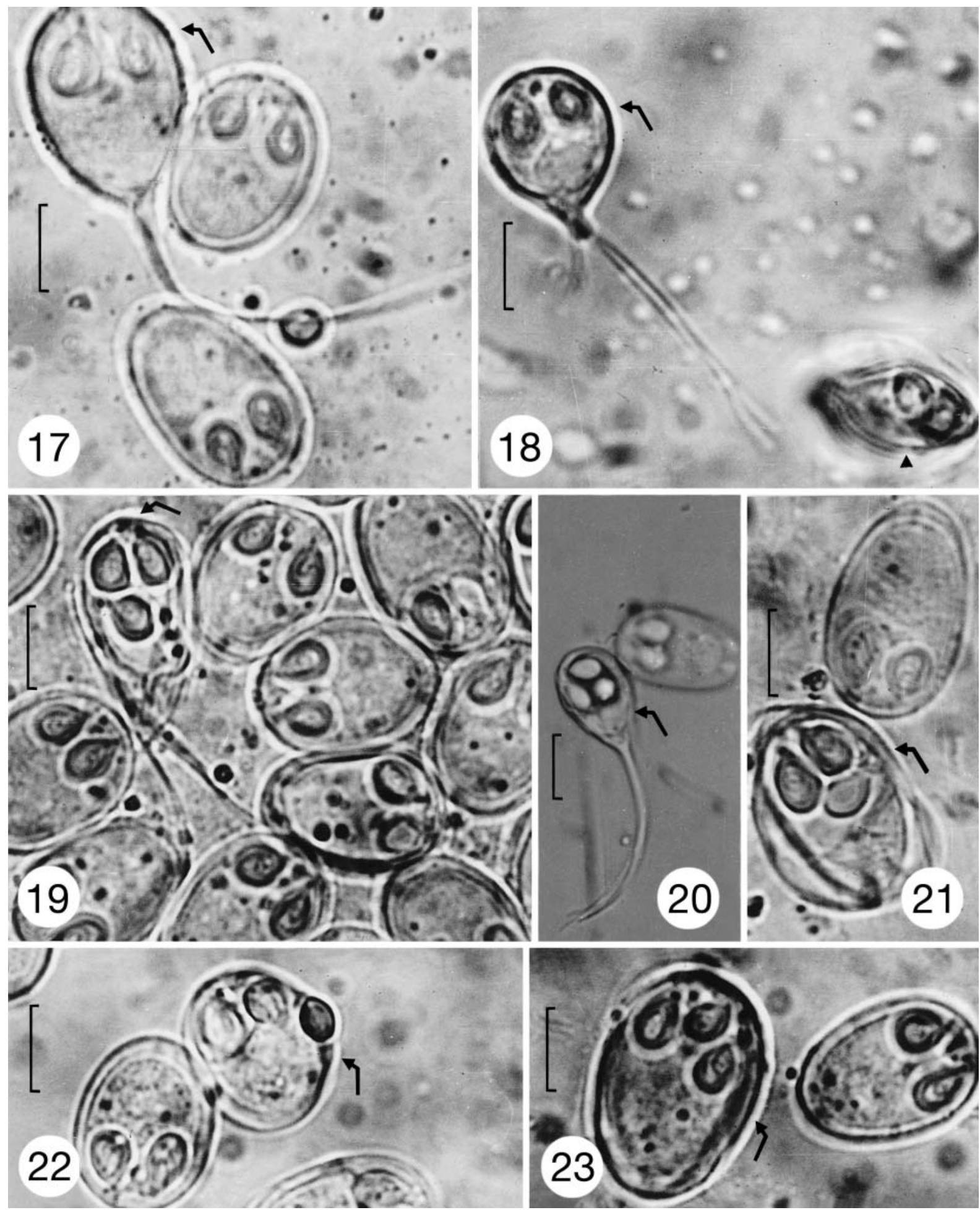

Various forms of Myxobolus heterosporus were photographed (Figs. 6 to 27), sketched (Figs. 28 to 48), measured (Table 1) and described (see below).

Description of spores. Five types of spores from Myxobolus heterosporus were distinguished according to shape (Figs. 5 to $8 \& 24$ to 28 ) and size (Table 1).
Type 1. Spores were ellipsoid in shape with a round anterior pole in frontal view. The polar capsules were of equal size and pyriform in shape. A little thickening was seen at the posterior end of the spore. The number of polar filament coils was 4 turns in each capsule (Figs. 5 (arrow) \& 24). 
Type 2. Spores were sub-spherical in shape. The polar capsules were ellipsoid to ovoid in shape and were situated at the anterior end of the spore. Polar filament coils 4 turns in each capsule (Figs. 5 (arrowhead) \& 25).

Type 3. Spores were ellipsoidal in shape with their width greatly exceeding the length. The polar capsules were pyriform in shape. Polar filament coils 3 to 4 turns. Sporoplasm fills up spore cavity and is seen around the polar capsules (Figs. 6 (arrow) \& 26).

Type 4. Spores were ellipsoidal to sub-ovoid in frontal view. The polar capsules were pyriform to elliptical with a tapering anterior end. The number of polar filament coils was probably 4 turns in each capsule. Spores had a round anterior end. These spores exhibited a cub base-like appearance at the posterior end (Figs. 7 (arrow) \& 27). Some other spores occasionally had a pointed anterior end and/or appendage-like structures at their posterior end; however, these may be of a different type (Fig. 46).

Type 5. Spores were elliptical in frontal view with rounded anterior and posterior ends. The 2 polar capsules were of equal size and were situated anterior parallel to each other. The number of polar filament coils was 4 turns, regularly arranged in each polar capsule (Figs. 8 (arrowhead) \& 28).

Spores of Myxobolus type 5 were most frequently formed, followed by spores of type 1, type 4 and type 2 respectively. Few spores resembled type 3 morphology.

\section{Evidence of transitional stages from Myxobolus-like morphology to tailed-spores}

Immature stages. Immature stages were shown with different aspects of sporoplasm and spore body. They changed from sub-spherical to ellipsoid shape to become somewhat elongated (Figs. 8 to $10 \& 29$ to 31 ). The polar capsules were pyriform to ovoid in shape. Polar filament coils 4 turns in each polar capsule. Spores of these stages must belong to Myxobolus unless they are specific immature stages for certain tailed-spore. These could be transition stages to socalled tailed-spore 1 (stage 4) (Fig. 11). The spore of stage 1 (Figs. 8 (arrow) \& 29) was considered the original immature stage of this tailed-spore, having developed simply through an extension of a spore valve at the posterior extremity to form a short tail (Figs. 11 \& 32).

Tailed-spores. Spores with a tail at the posterior end were found together with Myxobolus in one plasmodium. The examination was continued over several months to distinguish the present forms. They were less common, with a small number sometimes detected together with other Myxobolus-like spores. Lengthy examination was necessary to detect them. Spores were observed in several forms and stages of various shapes and sizes of spore body and tail. Tailed-spores were distinguished on the basis of shape (Figs. 11 to 17 $\& 32$ to 38 ) and size (tailed-spore 1 to 7 in Table 1).

In the present study, most tailed-spores may belong to Henneguya Thelohan, 1892 as in Figs. 13, 14, 16 \& 21; some others may belong to different genera such as Unicauda Davis, 1944 as in Figs. 11, 12 \& 15 and some spores which were of a Myxobolus-like structure, with minor differences in size and shape, might be considered as immature stages of tailed-spores (Figs. 8 to 10.

Description of tailed-spores. These spores were ellipsoid or sub-round and/or ovoid-shaped in frontal view. The polar capsules were not more than one-third the length of the spores. The number of polar filament coils was 4 turns in each capsule. Tails of various lengths were clearly visible at the posterior extremity of the spore valve.

Abnormal forms. Rare spores of different aspects with unusual characters were observed. They differed in size (Table 1; Abnormal forms 1 to 7 ) and shape (Figs. 18 to 23, 39 to 45). Some spores with abnormal tail appearance (Figs. 18, 19) of unusual shape (Figs. 18 (arrow) \& 20), with 3 polar capsules (Figs. 19 to 23), with abnormal locus of the polar capsule (Fig. 22) or with unusually shaped shell valves (Fig. 21) were distinguished.

Transmission electron microscopy. The presence of Myxobolus-like tailed-spores in one plasmodium, which dislodged from the cornea of the infected fish, was observed (Fig. 46).

\section{DISCUSSION}

All present spores were described from the plasmodium, which was surrounded by a smooth thin membrane. According to Lom \& Arthur (1989) and Molnár (1994) it is well recognized that the myxosporean parasite must be described from its original plasmodium. Early developmental stages were near to the plasmodium wall whereas mature spores were observed at the center, in agreement with the findings of Ali (1999) and El-Mansy (2002) on different species and hosts. Therefore, it may be postulated that the species should be described from the center of the plasmodium. A large number of plasmodia occupied a wide area of the cornea tissue. In agreement with Mazen (1994) this infection may affect fish vision.

This study offers a description of Myxobolus heterosporus that categorized into 5 main types, as well as tailed-spores and abnormal forms. This species appeared in a wide variety of shapes and sizes, and was therefore named $M$. heterosporus. Heteromor- 


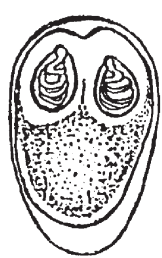

24

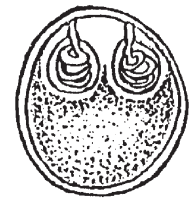

25

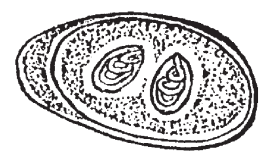

26

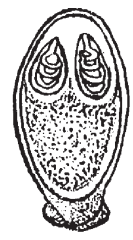

27

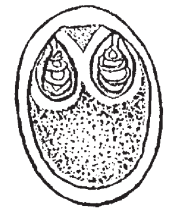

28
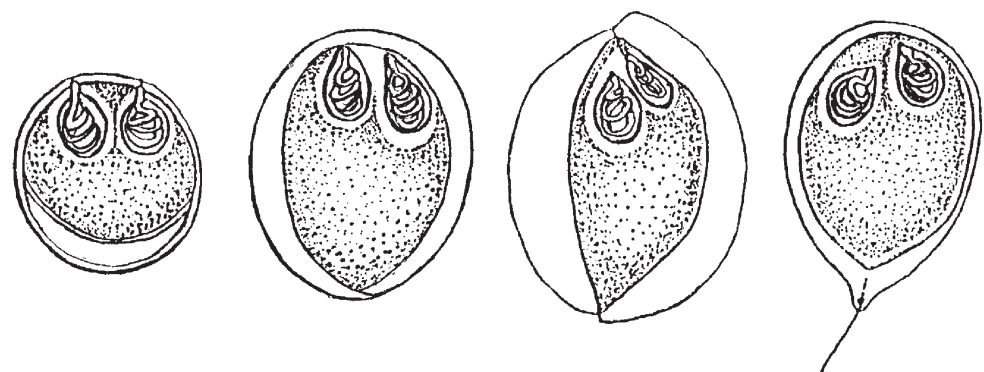

32

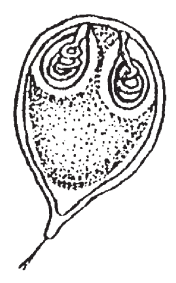

33

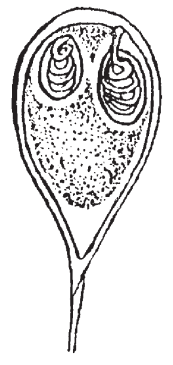

34

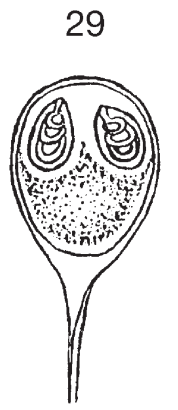

35

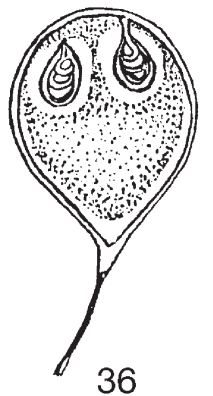

31
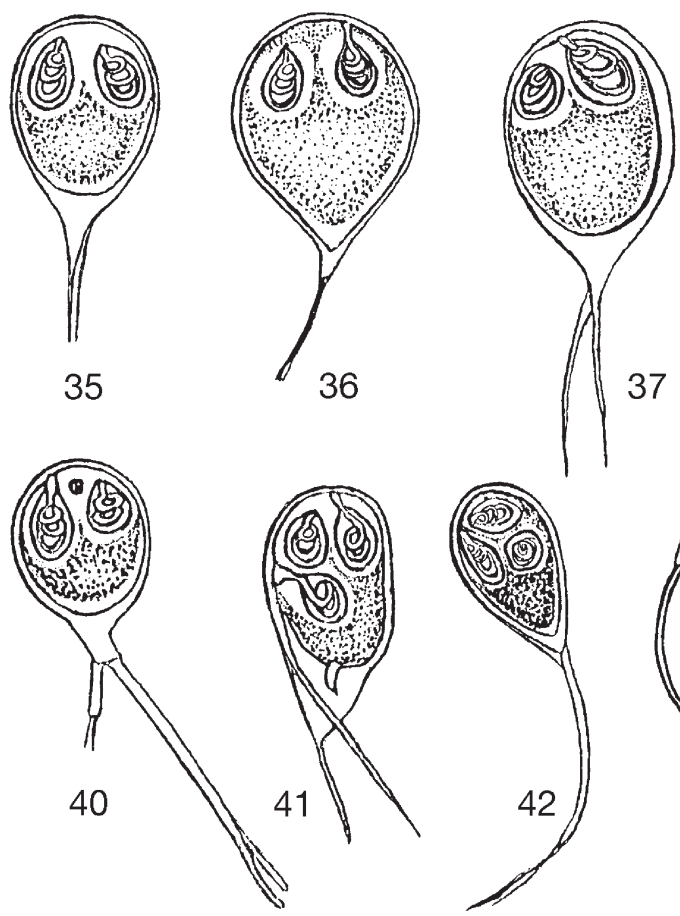

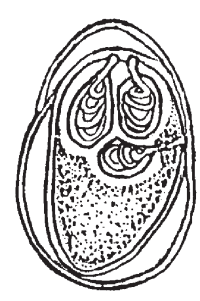

43
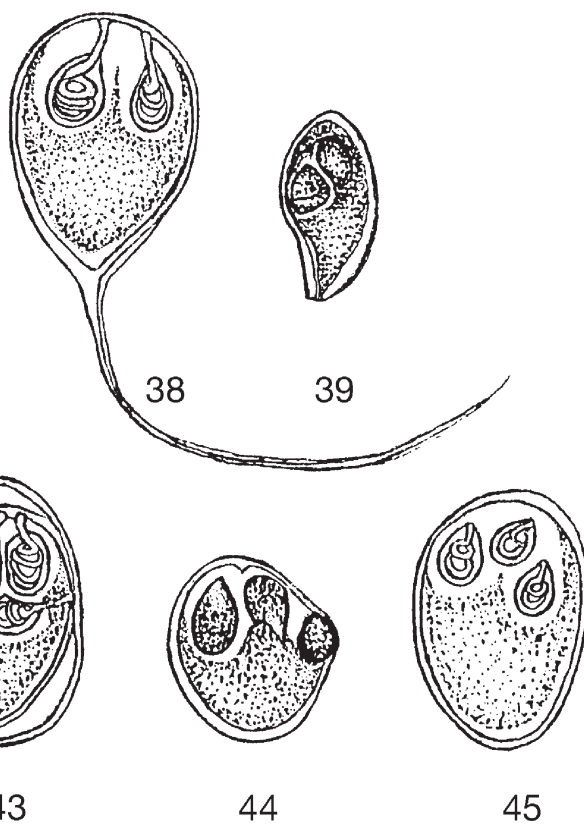

Figs. 24 to 45. Myxobolus heterosporus. Schematic illustration of types (Figs. 24 to 28), immature stages (Figs. 29 to 31), tailedspores (Figs. 32 to 38, 40 to 42) and abnormal forms (Figs. 39 to 45) spores infecting cornea of Oreochromis aureus, O. niloticus and Tilapia zillii. Figs. 24 to 28. Types 1 to 5 respectively. Figs. 29 to 31. Immature stages 1 to 3 respectively. Figs. 32 to 38 . Tailedspores 1 to 7 respectively. Fig. 39. Abnormal form 1. Figs. 40 to 42 . Abnormal form 2 (tailed-spore 8), abnormal form 3 (tailed-

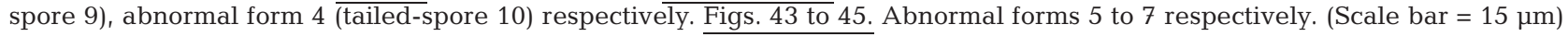

phism, or what Landsberg (1985) described as polymorphism, may account for the wide variety of $M$. heterosporus spores.

The present Myxobolus heterosporus cannot be directly compared with many species described by several investigators, because wide variations in the shape, somewhat in the size, and other names for species rather than $M$. heterosporus were described. The only similar- ity was the site of infection. As reported by Fomena \& Bouix (1997), Obiekezie \& Okaeme (1990) isolated $M$. galilaeus from eyes, kidney and spleen of several tilapias and M. homeosporus Baker, 1963 from the cornea of Oreochromis niloticus in Nigeria. Fomena et al. (1993) cited M. camerounensis from eyes, gills and muscles of O. niloticus in Cameroun. Fomena \& Bouix (1994) reported M. kribiensis from eyes, skin and kidneys of 
Fig. 46. Transmission electron micrograph of a plasmodium of Myxobolus heterosporus dislodged from the inner wall of the cornea tissue of the tilapian fish showing a so-called tailed-spore (T) together with Myxobolus-like spores (arrows) or probable immature stage spores. Note appendage-like structures at the posterior end of some spores. The polar filament coils in each polar capsule (Pc) may have been damaged during sectioning or may be due to fixation artifacts. (Scale bar $=2 \mu \mathrm{m})$

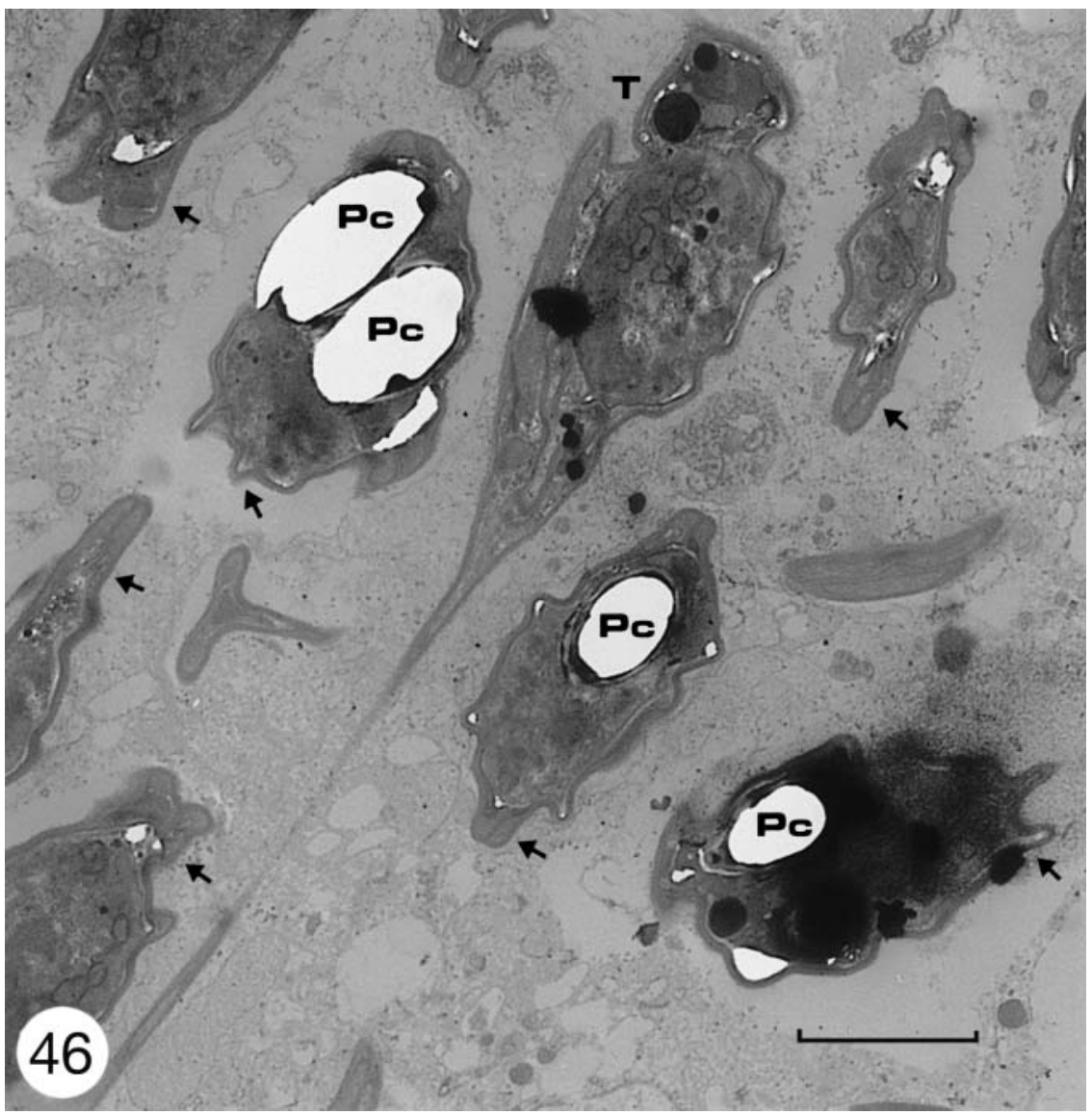

Brycinus longipinnis in Cameroun. Kostoingue \& Toguebaye (1994) isolated M. nyongana Fomena, Bouix \& Birigi, 1985 from eyes and gills of Alestex dentex and Labeo parvus in Chad. In addition Faisal \& Shalaby (1987) detected M. nilei (syn. Myxosoma tilapiae) from eyes, skin, gills, kidney, spleen and pancreas of $O$. niloticus, and Hegazy (1999) isolated M. cornealis from the eye of $O$. aureus and $O$. niloticus in Egypt.

It was possible to compare the present parasite with some previously described Myxobolus heterosporus (syn. Myxosoma heterospora) from the eyes of some tilapias. Abed (1987) described Myxobolus heterosporus (syn. Myxosoma heterospora) from eye, muscle and kidney of Oreochromis niloticus. The spores measured $(15.2-17.8) \times(9.8-11.8) \mu \mathrm{m}$ with polar capsules dimensions of $(4.3-5.6) \times(2.8-3.6) \mu \mathrm{m}$. Moreover, Mazen (1994) described Myхobolus heterosporus (syn. Мухоsoma heterospora) from eye and gills of Oreochromis niloticus. The spores measured $(14-18) \times(8-11) \mu \mathrm{m}$ and the polar capsules of $(4-6) \times(2.4-3.8) \mu \mathrm{m}$. The spores described by Abed (1987) and those described by Mazen (1994) were compared with the spores of the present study. Considerable differences in shape and minor similarities in size were observed but they may be similar to the type 1 or type 5 spores in the present study.
Spores of Myxobolus sp.1 as described by AbdelGhaffar et al. (1995) from the inner wall of cornea, the base of the gill arch, roof of the mouth and internal surface of the operculum of Oreochromis aureus and O. niloticus measured $17.9(16.2-18.9) \times 11.1(10.8-12.6) \mu \mathrm{m}$ with polar capsules dimensions $5.0(3.6-6.3) \times 3.5(2.6-3.6) \mu \mathrm{m}$. Although a minor difference in spore body length of Myxobolus sp.1 was observed, there was marked a similarity in terms of the size and shape size of the polar capsules particularly with the present spores of type 4 .

In the present parasite, most polar capsules had the same number of filament coils i.e. usually 4 , with the exception of a few spores which had 3 or 5 . This is in agreement with the findings of Abdel-Ghaffar et al. (1994) on Myxobolus sp.1 from cornea in that the number of polar filament coils was 3 to 5 turns in each mature polar capsule versus 4 for most present spores. This may suggest that Myxobolus sp.1 was similar in particular to the type 1 and/or type 5 spores of the present parasite.

In the present study, a few spores with abnormal morphology, especially those with 3 polar capsules were detected. Abdel-Ghaffar et al. (1994) reported that Myxobolus sp.1 sometimes had 3 valves, which was similar to myxosporean spore of genus Trilospora (Lom \& Dyková 1992). 


\section{Tailed-spores}

Tailed-spores may emerge from spores of a Myxobolus-like shape, and these spores might be the immature stages for some tailed-spore. Therefore, Myxobolus at certain immature stages could develop to tailed-spores through the extension of their shells at the posterior extremity to form the tailed-spore. This may be supported by the findings of Abdel-Ghaffar et al. (1994) who reported that the valvogenic cells of Myxobolus sp. 1 gave rise to 2 valves similar to those reported in Henneguya adiposa (Current 1979). The present finding may also support the suggestion of Andree et al. (1999) who reported that 18s rDNA sequence data do not support a phylogenetic separation of the 2 major genera Henneguya and Myxobolus. In addition, Kent et al. (2001) suggested that the caudal appendages on spore valves, which distinguish Henneguya from Myxobolus, arose on multiple occasions and is not a valid character to separate these species groups into 2 separate genera. Therefore, in the present study, tailed-spores may have emerged from Myxobolus. In this case, tailed-spores may simply be heteromorphic forms of Myxobolus.

Finally, experimental transmission in other hosts and also further molecular evidence for the present species should be the subject of further study.

Acknowledgements. The constructive comments given by anonymous reviewers greatly improved the manuscript. I am also grateful to Dr. M. Ali for his comment.

\section{LITERATURE CITED}

Abdel-Ghaffar F, Abdel-Aziz A, El-Shahawi G, Naas S (1994) Light and electron microscopic studies on Myxobolus sp. infecting Oreochromis (Syn: Tilapia) niloticus and $O$. aureus in the River Nile. J Union Arab Biologists 2:241-261

Abdel-Ghaffar F, El-Shahawi G, Naas S (1995) Myxosporidia infecting some Nile fishes in Egypt. Parasitol Res 81:163-166

Abed GP (1987) Studies on Myxosporidia of some Nile fishes in Assuit province. MSc thesis, Assuit University, Egypt

Abolarin MO (1974) Myxobolus tilapiae sp. nov. (Protozoa: Myxosporidia) from three species of freshwater Tilapia in Nigeria. J West Afr Sci Assoc 19:106-114

Ali M (1999) Henneguya ghaffari sp. n. (Myxozoa: Myxosporea) infecting the Nile perch Lates niloticus (Teleostei: Centropomidae). Dis Aquat Org 38:225-230

Ali M, Al-Rasheid K, Sakran T, Abdel-Baki A, Abdel-Ghaffar F (2002) Some species of the genus Myxobolus (Myxozoa: Myxosporea) infecting freshwater fish of the River Nile, Egypt, and the impact on their hosts. Parasitol Res 88:9-15

Andree KB, Szekely C, Molnar K, Gresoviac SJ, Hedrick RP (1999) Relationships among members of the genus Myxobolus (Myxozoa: Bivalvulida) based on small subunit ribosomal DNA sequences. J Parasitol 85:68-74

Ashmawy KI, Abou El-Wafa SA, Imam EA, El-Otifi YZ (1989) Description of newly recorded Myxosporidia protozoa of freshwater fishes in Behara Province. Egypt Ass Vet Med J 49:43-53

Baker JR (1963) Three species of Myxosoma (Protozoa: Myxo- sporidia) from East African freshwater fish. Parasitology 53: 285-292

Current WL (1979) Henneguya adiposa Minchew (Myxosporidia) in the channel catfish ultrastructure of plasmodium wall and sporogenesis. J Protozool 26:209-217

Dyková I (1982) The bearing of melano-macrophages to myxosporean infections in cyprinid fishes. J Protozool 29:502-503

El-Mansy A (2002) Immature stages and re-description of Henneguya suprabranchiae Landsberg, 1987 (Myxosporea: Myxobolidae) an intestinal parasite of the catfish Clarias gariepinus in the River Nile, Egypt. Dis Aquat Org 51:179-186

El-Mansy A, Abdel-Ghaffar F (2003) Tilapian proliferative kidney disease (TPKD) and using the kidney as a diagnostic evidence for the presence of myxosporean parasites. J Egypt Ger Soc Zool 40:139-159

Fahmy M, Mandour A, El-Naffar M (1971) Myxobolus niloticus in the fish Labeo niloticus from the River Nile of Assiut. J Egypt Soc Parasitol 1:39-46

Faisal M, Shalaby S I (1987) Myxosoma tilapiae as a new species (Myxozoa: Myxosporea) in wild Oreochromis niloticus in lower Egypt. Egypt J Vet Sci 24:73-86

Fomena A, Bouix G (1994) New Myxosporidea species (Myxozoa) from freshwater teleosts in Southern Cameroun (Central Africa). Zool 108:481-491

Fomena A, Bouix G (1997) Myxosporea (Protozoa: Myxozoa) of freshwater fishes in Africa: keys to genera and species. Syst Parasitol 37:161-178

Fomena A, Marques A, Bouix G (1993) Myxosporidea (Myxozoa) of Oreochromis niloticus (Linnaeus, 1757) (Teleost: Cichlidae) in fish-farming pools at Melen (Yaounde, Cameroun, Central Africa). J Afr Zool 107:45-56

Hegazy A (1999) Light and electron microscopic studies on Myxozoan infecting some Egyptian fishes in Bahr Shebin Canal. MSc thesis, Menoufia University, Egypt

Imam EA, Ramadan EI, Derhalli FS (1987) On some internal protozoa infecting some Nile fishes in Egypt. J Egypt Vet Med Ass 47:55-61

Kent ML, Andree KB, Bartholomew JL, El-Matbouli M and 12 others (2001) Recent advances in our knowledge of the Myxozoa. J Eukaryot Microbiol 48:395-413

Kostoingue B, Toguebaye BS (1994) Le genre Myxobolus (Myxozoa: Myxosporea) chez les poissons d'eau douce du Tchad avec la description de trois nouvelles especes. Bull Inst Foundamental Afrique Noire 47:63-71

Koura EA (2000) Kudoa aegyptia sp nov (Myxosporea: Multivalvulida) in the heart muscle of fish Haffara Rhabdosargus haffara (Forsskal, 1775) from Egypt. Egypt J Zool 34:1-26

Landsberg JH (1985) Myxosporean infections in cultured tilapias in Israel. J Protozool 32 (1):194-201

Lom J (1969) On a new taxonomic character in Myxosporidia, as demonstrated in descriptions of two new species of Myxobolus. Folia Parasitol 16:97-103

Lom J, Arthur JR (1989) A guideline for the preparation of species description in Myxosporea. J Fish Dis 12:151-156

Lom J, Dyková I (1992) Protozoan parasites of fishes. Elsevier Science Publishers, Amsterdam

Mazen AM (1994) Effect of the protozoan parasite, Myxosoma heterospora on the eye of fish Tilapia nilotica. Assiut Vet Med J 31:121-129

Molnár K (1994) Comments on the host organ and tissue specificity of fish myxosporeans and on the types of their intrapiscine development. Parasitol Hung 27:5-20

Obiekezie AI, Okaeme AN (1990) Myxosporea (Protozoa) infections of cultured tilapias in Nigeria. J Afr Zool 104: 77-91

Paperna I (1968) Ectoparasitic infections of fish in Volta Lake, Ghana. Bull Wildl Dis Assoc 4:135-137 